\title{
Identification and Removal of Nonoriginal Layers in the 16th Century Paintings of Funchal's Cathedral Altarpiece
}

\section{Sofia Gomes, ${ }^{1}$ Carolina Ferreira, ${ }^{2,3}$ Glória Nascimento, ${ }^{2,3}$ Luís Piorro, ${ }^{1}$ Ana Cardoso, ${ }^{3}$ António Candeias, Mercês Lorena ${ }^{1 *}$}

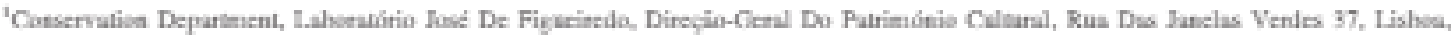 \\ Purtagal
}

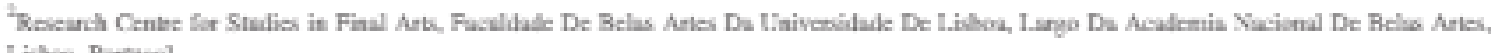
t.iblos, Puntagal

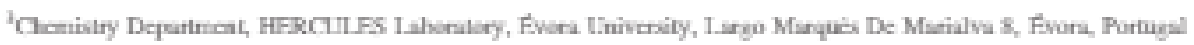

\begin{abstract}
This article is an oufcome of the study, deci sians, and restoration wovk undertaken during the inte grated conservation project of the I6th century paintings of Fumchal's Cathedral main chapel's altavpiece, in Madeina Island, Portugal. After diagnostic research has allowed a complete understanding of the original mate rial of the 12 Portuguese-Flemish paintings, it has been revealed the presence of other superimposed layers. whether actual overpaints or the accumulation of materi als occurring in time over the ald ones. Identification together with the cleaning and removal of these coatings was a delicate and a complex process. Conservators already suspected the existence of overpaints in some paintings, a close observation of the painted surface showed differences in terms of colar, texture, and execat tion technique in sperific areas. Chemical and strati graphical research together with radiography and histarical research on primary documental sources pro vided important clues about the paintings of the previous interventians and relevant and crucial information for the decision making- 2016 Wilcy Priodicak, lac Col Res Appl, 41, 283-285, 2016, Putlishal Online 11 Felnuary 2016 in Wiley Onlise 1.ileary (Willeyuslinclitnary.coe). DOt $10.1002 / 601.220027$
\end{abstract}

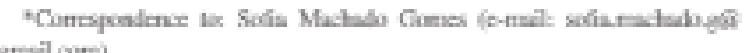
grialiours:

62016 Wiley Periafusts, lac
Key words: restoration; conservation; painting; over paint; cleaning

\section{THE PAINTINGS HISTORY}

The Funchal altappiece condered by King Manuel I is the caly Portuguese remsining monumental altarpiece from the 16th century that is still in its original lexcation. The 12 paintings of Funchal's Cathedral main chappel's altarpiece had a very unsatisfactory appearance; the sarface was very dark beciase of the many layers of grime, coxatings, and materials from the previous interventions. Obviously, the printings had endured numervus interventions. Since the end of the 16th century to the 19th century, the altarpiece was subrritted to "repaintings," "renovations," and "washings" that resulted in changes and additions to its original surface."

Since the 17th century in Eurupe, varied and unexpected products and methods are described in clesaning recipes in handhooks and prainting treatises. Scap, blexach, egg white, lime water, butter, ashes, and even urine were some of the products used to clean the printings at this time. ${ }^{2}$ Haxands of pxinting cleaning and the concem about the consequences of clearing are also mentioned in sceme of these trextises (Pachecos'), the we of acids and allkali mixtures in antique restroations resulted in marry overcleaned paintings and irreparahle danage. Furthemore, with the purpose of reviving colves, the psintings were inupregnated with covked cils, varnish byers, and bitumen, ${ }^{2}$ which furmed a hetenugenesus and darkened byer pre venting the display of the psintings' arigirsal colkr. 